\title{
Clay mineralogical characterization of a toposequence of perhumid subalpine forest soils in northeastern Taiwan
}

\author{
Chuang-Wen Pai ${ }^{\mathrm{a}}$, Ming-Kuang Wang ${ }^{\mathrm{b}}$, Chih-Yu Chiu ${ }^{\mathrm{a}, *}$ \\ ${ }^{a}$ Research Center for Biodiversity, Academia Sinica, Taipei 11529, Taiwan \\ ${ }^{\mathrm{b}}$ Department of Agricultural Chemistry, National Taiwan University, Taipei 10764, Taiwan
}

Received 1 February 2006; received in revised form 8 November 2006; accepted 8 November 2006

Available online 29 December 2006

\begin{abstract}
We have investigated the clay mineralogy of 3 pedons along a toposequence of perhumid forest soils facing a subalpine lake in northeastern Taiwan to gain insight into the individual factors that affect weathering rates. Toposequence of the transect was investigated from summit to footslope and at the lakeshore. The natural drainage of soils varies from well drained to poorly drained. The major minerals in the well-drained soils at the summit site were illite and kaolinite, whereas illite and vermiculite were dominant in the poorly drained soil at the footslope. In the poorly drained soils of the lakeshore site, almost permanent saturation inhibited weathering of minerals, and vermiculite, illite and illite-vermiculite were the dominant minerals. The magnitude of the mean layer charge of vermiculite was estimated by use of the alkylammonium exchange method $(n \mathrm{C}=12)$. The mean layer charge of vermiculite ranged between 0.63 and $0.78 \mathrm{cmol}_{\mathrm{c}} /\left(\mathrm{O}_{10}(\mathrm{OH})_{2}\right)$. The distribution of clay layer charge varied with location and soil depth. Vermiculite in the surface horizons displayed lower mean layer charges, indicating stronger weathering intensity in the surface horizons. Acidification by organic acids may result in the reduction of layer charge in vermiculite, particularly at the surface. Differences in layer charge with landscape position may be due to differences in weathering processes. The drainage condition caused by topography is a critical factor in the transformation and redistribution of clay minerals. High precipitation, combined with surface runoff, enhance the variation of the type and mean layer charge of clay minerals along this toposequence.
\end{abstract}

(C) 2006 Elsevier B.V. All rights reserved.

Keywords: Clay minerals; Forest soils; Mean layer charge toposequence; Weathering; X-ray diffraction

\section{Introduction}

The identification of the formation of clay minerals has important implications for a diverse range of geochemical issues (Berner and Lasaga, 1989; Egli et al., 2004). Weathering of primary minerals in forest ecosystems is the most important long-term process that counteracts soil acidification and base depletion. Therefore, the mechanisms and rates of the weathering of clay minerals are critical to assess soil fertility and to predict the long-term stability of forest ecosystems (Gillot et al., 2001).

The magnitude of the layer charge is a key parameter in the classification of layer silicates (Bailey, 1980). Layer charge is also an important characteristic of 2:1 phyllosilicates since it determines the capacity of a given mineral in the group to retain

\footnotetext{
* Corresponding author. Tel.: +886227892386.

E-mail address: bochiu@sinica.edu.tw (C.-Y. Chiu).
}

cations and adsorb water and various polar organic molecules (Malla and Douglas, 1987; Mermut, 1992; Malla et al., 1993). Chemical analyses are unsuitable for layer charge determination, because soil clays generally contain non-phyllosilicate impurities as well as minerals with variable charge. Intercalation with alkylammonium ions is the most commonly used method to determine the magnitude of the layer charge in mineral mixtures (Lagaly, 1981, 1993). Rühlicke and Kohler (1981) refreshed the method for the preparation of $n$-alkylammonium as an intercalation agent for mean layer charge determination because it is reliable and less time-consuming. The mean layer charge is determined by the relative proportions of bilayers to monolayers (or pseudotrilayers to bilayers) as indicated by peak migration curve analysis of instratified spacing (Gillot et al., 2001). Thus, Olis et al. (1990) also proposed an empirical method to determine the mean layer charge of $2: 1$ clay minerals from $d$-values obtained after expansion with a single long-chain alkylammonium $(n \mathrm{C}=12)$. 
The prediction of soils in specific landscape positions has received considerable attention during the past decades (Furley, 1968; Davidson, 1977; Dalsgaard et al., 1981). Topography is one of critical factors in the development of different soils within a given locality, which affects drainage water. Since drainage influences the moisture regime, seepage, redox potential, and ionic environments, transformation of clay minerals and metal oxides would also be affected by weathering (Hall, 1983). Clay mineralogy and layer charge of 2:1 clay minerals in the soil in the forest-covered, rapid-up-lifting, and erosive mountainous areas of Taiwan have been little investigated. We aimed to clarify the topographic effect on the distribution of clay minerals in pedogenetic processes and identify the main factors responsible for variable layer charges of 2:1 phyllosilicates within subalpine forest soil profiles under perhumid conditions.

\section{Materials and methods}

\subsection{Site descriptions}

The Yuanyang Lake ecosystem $\left(24^{\circ} 35^{\prime} \mathrm{N}, 121^{\circ} 24^{\prime} \mathrm{E}\right)$ in northeastern Taiwan was selected for this study (Fig. 1). The locality is $1700-2200 \mathrm{~m}$ above sea level, at which the annual mean temperature and precipitation are $12.5^{\circ} \mathrm{C}$ and $>4000 \mathrm{~mm}$, respectively. The soils are covered with primary forest, dominated by Taiwan false cypress (Chamecyparis formosensis) and an evergreen broadleaf shrub (Rhododendron formosanum). This locality can be described as a temperate, very wet and mountainous ecosystem. The parent rock is composed of interbedded Tertiary shale and sandstone (Ho, 1988).
The forest soils are divided into 3 main groups, which are closely related to the landscape. The soil at the summit site is classified as Typic Hapludult (Soil Survey Staff, 1998), a relatively well-drained soil with clear eluvial and illuvial boundaries. The mineral soil has an argillic horizon with thick clay skin. Typic Dystrochrept is predominant on the footslope. The presence of a silty-clayey mineral horizon beneath the organic layer restricts drainage and the downward movement of soluble compounds, hampering the soil profile development. Lithic Medihemist stretches from the lakeshore to the toeslope. The thick organic layer lies directly on the primarily weathered rock. The lakeshore site is about $1.5 \mathrm{~m}$ away from the lake and is inundated by the occasional storm. Details of the environment of this ecosystem have been given by Chiu et al. (1999) and Chen and Chiu (2000).

\subsection{Soil sampling}

We selected 3 representative pedons along a topographic sequence. At each study site, a pit was excavated for the description of macromorphological soil characteristics as well as for the collection of soil samples according to standard procedures (Soil Survey Staff, 1993). The soil samples were air dried and crushed to pass through a 2-mm sieve.

\subsection{Analytical methods}

Particle-size distribution was determined by the pipette method (Gee and Bauder, 1986). Soil $\mathrm{pH}$ was measured at a soil:water ratio of 1:1 (McLean, 1982). Organic $\mathrm{C}$ and total $\mathrm{N}$ in the soil were determined with an NCS Elemental Analyzer

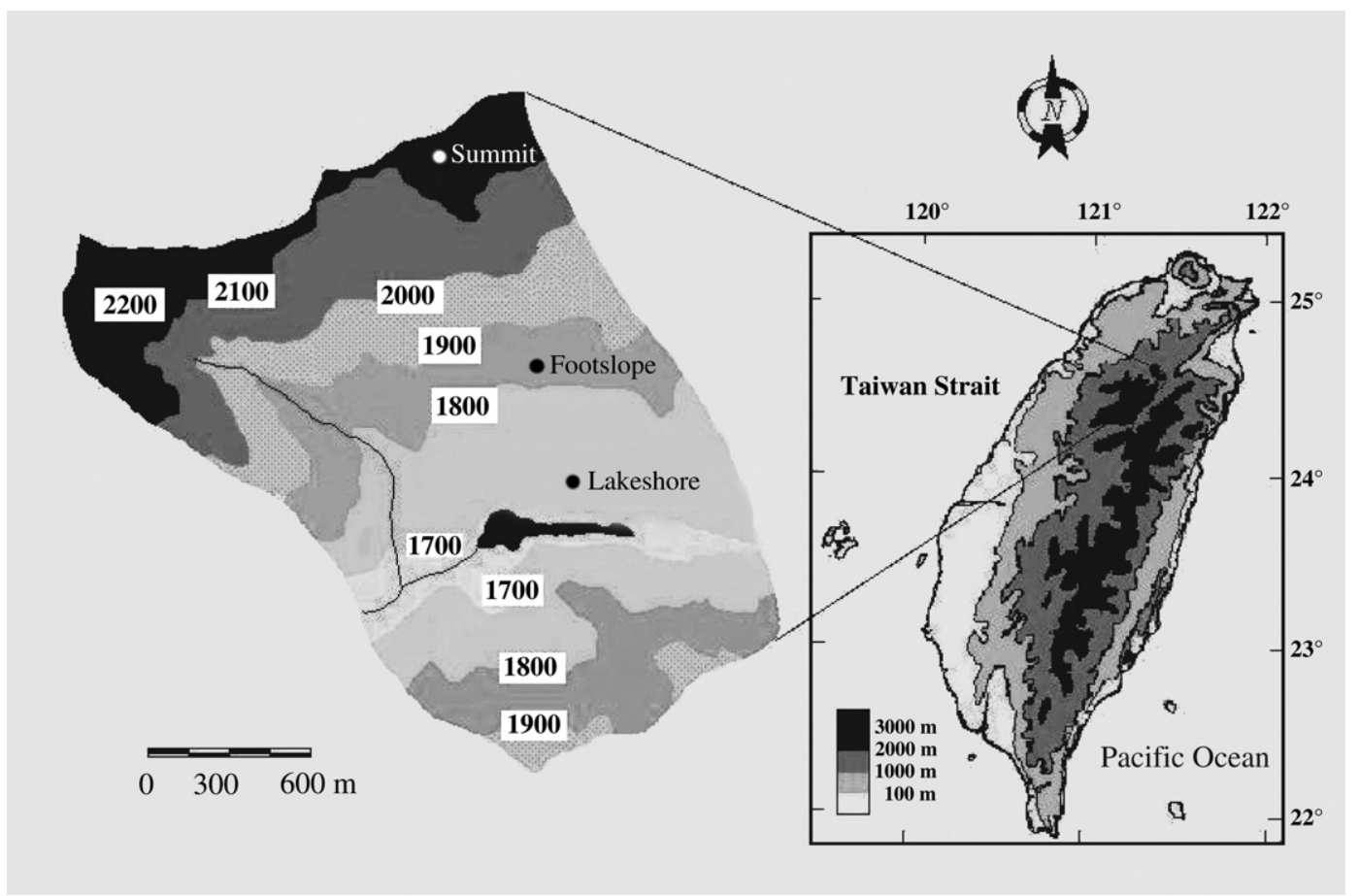

Fig. 1. Map of study site. Symbols indicate the location of sampling. 
(Model NA1500 Fisons, Italy). Cation-exchange capacity was determined by the $\mathrm{NH}_{4} / \mathrm{Na}$ exchange method (Rhoades, 1982). Dithionite-citrate-bicarbonate $\mathrm{Fe}\left(\mathrm{Fe}_{\mathrm{d}}\right)$ and $\mathrm{Al}\left(\mathrm{Al}_{\mathrm{d}}\right)$ were obtained by Mehra and Jackson's (1960) method.

The clay fraction $(<2 \mu \mathrm{m})$ was separated by wet sieving, gravity sedimentation and centrifugation (Jackson, 1979). The samples were pretreated with $10 \% \mathrm{H}_{2} \mathrm{O}_{2}$ on a hot plate to remove most of the organic matter. Soil samples containing high amounts of organic matter were transferred to $1000-\mathrm{mL}$ beakers. An amount of $5 \mathrm{~mL} \mathrm{H}_{2} \mathrm{O}_{2}$ was added to the soil suspension, which was stirred, covered and observed closely for several minutes. If excessive frothing occurred, the container was cooled in cold water. More $\mathrm{H}_{2} \mathrm{O}_{2}$ was added when the reaction subsided. The solution was heated to $90{ }^{\circ} \mathrm{C}$ when frothing ceased, and the cover was removed to evaporate excess water. $\mathrm{H}_{2} \mathrm{O}_{2}$ and heat treatment was continued until most of the organic matter was destroyed (as judged by the rate of reaction and the bleached color of the sample). The samples were heated for about an hour after the final addition of $\mathrm{H}_{2} \mathrm{O}_{2}$ to destroy excess $\mathrm{H}_{2} \mathrm{O}_{2}$. Clay samples were saturated with $\mathrm{Mg}$ and $\mathrm{K}$ and mounted as slurries on glass slides for X-ray diffraction (XRD) analysis. The air-dried Mg-saturated samples were analyzed at $25{ }^{\circ} \mathrm{C}$ followed by glycerol solvation. The air-dried K-saturated samples were analyzed at $25^{\circ} \mathrm{C}$ and then heated at 110,250 , 350,450 and $550{ }^{\circ} \mathrm{C}$. Semi-quantitative estimates of the proportions of the clay minerals were derived from peak area measurements (Brindley, 1980; Pai et al., 1999).

Dodecylammonium chloride was prepared from dodecylamine according to the procedure of Rühlicke and Kohler (1981). Intercalation with dodecylammonium was carried out by heating $30 \mathrm{mg}$ of Na-saturated, freeze-dried clay in a $75 \mathrm{~mL}$ aliquot of $0.1 \mathrm{M}$ dodecylammonium chloride solution at $65^{\circ} \mathrm{C}$ for 2 days (Lagaly, 1982). Excess reagent was removed by 8 washings with a water:ethanol (1:1) mixed solution and 2 final washings with pure ethanol. Oriented mounts were prepared by transferring the clay suspensions onto glass slides and drying under vacuum at $65{ }^{\circ} \mathrm{C}$ for $24 \mathrm{~h}$. All X-ray diffractograms were recorded with a Rigaku Miniflex X-ray diffractometer equipped with $\mathrm{CuK} \alpha$ radiation generated at $35 \mathrm{kV}$ and $10 \mathrm{~mA}$. The XRD patterns were recorded from 3 to $40^{\circ} 2 \theta$ at a scanning speed of $2^{\circ} 2 \theta \mathrm{min}^{-1}$. The mean layer charge of vermiculite was estimated by use of dodecylamine $(n \mathrm{C}=12)$ according to the alkylammonium ion-exchange method described by Pai et al. (1999, 2004). For the bilayer to transition to a pseudotrimolecular layer, the following equation was used:

$d_{001}=1.7023 \mathrm{MLC}+1.0435$

with $\mathrm{MLC}=$ mean layer charge and $d$-spacings given in nanometers (Pai et al., 1999).

\section{Results and discussion}

\subsection{Selected chemical and physical properties}

The soils at the 3 sites were strongly acidic, and the $\mathrm{pH}$ ranged from 3.3 to 4.5 . Texture of 3 soils was from clay to silty clay. Among all studied sites, the content of organic carbon in the surface horizon was greater than $352 \mathrm{~g} \mathrm{~kg}^{-1}$. Year-round high precipitation causes high soil moisture, and together with mild temperature, retards the decomposition of soil organic matter (Chen and Chiu, 2000). $\mathrm{Ca}^{2+}$ and $\mathrm{Mg}^{2+}$ were dominant

Table 1

Physical and chemical characteristics of soils at studied sites

\begin{tabular}{|c|c|c|c|c|c|c|c|c|c|c|c|c|c|}
\hline \multirow[t]{2}{*}{ Site } & \multirow{2}{*}{$\begin{array}{l}\text { Depth } \\
(\mathrm{cm})\end{array}$} & \multirow[t]{2}{*}{ Horizon } & \multirow[t]{2}{*}{ Texture $^{a}$} & \multirow{2}{*}{$\begin{array}{l}\mathrm{pH} \\
\left(\mathrm{H}_{2} \mathrm{O}\right) \\
\end{array}$} & \multirow{2}{*}{$\begin{array}{l}\text { Organic C } \\
(\mathrm{g} / \mathrm{kg}) \\
\end{array}$} & \multirow{2}{*}{$\begin{array}{l}\text { CEC } \\
\left(\mathrm{cmol}_{(+)} \mathrm{kg}^{-1}\right)\end{array}$} & \multicolumn{4}{|c|}{$\begin{array}{l}\text { Exchangeable cations } \\
\left(\mathrm{cmol}_{(+)} \mathrm{kg}^{-1}\right)\end{array}$} & \multirow{2}{*}{$\begin{array}{l}\mathrm{BS}^{\mathrm{b}} \\
(\%) \\
\end{array}$} & \multirow{2}{*}{$\begin{array}{l}\mathrm{Fe}_{\mathrm{d}} \\
(\mathrm{g} / \mathrm{kg})\end{array}$} & \multirow{2}{*}{$\begin{array}{l}\mathrm{Al}_{\mathrm{d}} \\
(\mathrm{g} / \mathrm{kg})\end{array}$} \\
\hline & & & & & & & $\mathrm{K}$ & $\mathrm{Ca}$ & $\mathrm{Mg}$ & $\mathrm{Na}$ & & & \\
\hline \multirow[t]{8}{*}{ Summit } & $0-2$ & Oi & - & 3.7 & 352.4 & 73.1 & 1.6 & 5.1 & 1.9 & 0.3 & 1.2 & 4.1 & 1.8 \\
\hline & $2-7$ & Oe & - & 3.5 & 492.5 & 124.9 & 0.8 & 0.7 & 2.4 & 0.3 & 3.3 & 2.6 & 2.2 \\
\hline & $7-10$ & $\mathrm{Oa}$ & - & 3.5 & 492.4 & 146.9 & 1.1 & 0.2 & 1.9 & 0.3 & 2.3 & 4.3 & 2.5 \\
\hline & $10-11$ & $\mathrm{~A}$ & - & 3.5 & 207.3 & 60.1 & 0.4 & 0.1 & 0.5 & 0.1 & 1.8 & 4.1 & 1.6 \\
\hline & $11-18$ & $\mathrm{E}$ & $\mathrm{SiC}$ & 3.8 & 38.0 & 19.5 & 0.5 & 0.2 & 0.1 & 0.1 & 4.6 & 1.9 & 1.0 \\
\hline & $18-30$ & Bt1 & $\mathrm{C}$ & 4.1 & 10.0 & 19.6 & 0.4 & 0.2 & 0.1 & 0.1 & 4.1 & 38.5 & 7.7 \\
\hline & $30-40$ & $\mathrm{Bt} 2$ & $\mathrm{C}$ & 4.2 & 11.9 & 12.4 & 0.4 & 0.2 & 0.1 & 0.1 & 6.5 & 41.3 & 7.8 \\
\hline & $40-55$ & $\mathrm{BC}$ & $\mathrm{SiC}$ & 4.3 & 9.0 & 12.7 & 0.1 & 0.2 & 0.1 & 0.1 & 3.9 & 34.9 & 7.5 \\
\hline \multirow[t]{7}{*}{ Footslope } & $0-4$ & Oi & - & 3.8 & 541.7 & 98.9 & 2.3 & 5.2 & 2.5 & 0.5 & 10.6 & 2.2 & 1.5 \\
\hline & $4-12$ & $\mathrm{Oe}$ & - & 3.5 & 511.8 & 120.3 & 1.0 & 2.6 & 2.4 & 0.4 & 5.3 & 3.0 & 1.2 \\
\hline & $12-15$ & $\mathrm{Oa}$ & - & 3.3 & 476.7 & 102.9 & 1.2 & 1.5 & 2.1 & 0.3 & 5.0 & 2.2 & 1.9 \\
\hline & $15-20$ & A & - & 3.5 & 237.6 & 65.3 & 0.5 & 0.5 & 0.5 & 0.2 & 2.6 & 18.3 & 4.0 \\
\hline & $20-25$ & $\mathrm{E}$ & $\mathrm{SiC}$ & 4.0 & 7.0 & 11.5 & 0.5 & 0.2 & 0.1 & 0.1 & 7.8 & 5.2 & 0.8 \\
\hline & $25-38$ & Bw1 & $\mathrm{SiC}$ & 4.1 & 10.0 & 16.6 & 0.1 & 0.1 & 0.1 & 0.1 & 2.4 & 25.9 & 4.5 \\
\hline & $38-57$ & $\mathrm{BC}$ & $\mathrm{C}$ & 4.5 & 19.9 & 17.6 & 0.4 & 0.1 & 0.2 & 0.1 & 4.5 & 27.0 & 3.9 \\
\hline \multirow[t]{3}{*}{ Lakeshore } & $0-9$ & Oi & - & 3.5 & 363.1 & 36.3 & 0.5 & 0.1 & 1.1 & 0.4 & 5.7 & 1.9 & 0.9 \\
\hline & $13-22$ & $\mathrm{Oe}$ & - & 3.4 & 186.7 & 18.7 & 0.3 & 0.1 & 0.9 & 0.2 & 8.0 & 3.7 & 0.8 \\
\hline & $22-33$ & $\mathrm{Oa}$ & - & 3.5 & 176.9 & 17.7 & 0.5 & 0.1 & 0.5 & 0.2 & 7.3 & 1.4 & 1.3 \\
\hline
\end{tabular}

$\mathrm{Fe}_{\mathrm{d}}$ : Iron extracted by the citrate-bicarbonate-dithionite method.

$\mathrm{Al}_{\mathrm{d}}$ : Aluminium extracted by the citrate-bicarbonate-dithionite method.

a - : not determined; SiC: Silty clay; C: Clay.

b Base saturation. 
exchangeable cations and decreased with increasing depth. A low percentage of base saturation was mostly due to the strong leaching processes. Amounts of $\mathrm{Fe}_{\mathrm{d}}$ and $\mathrm{Al}_{\mathrm{d}}$ reached the maximum levels in the $\mathrm{Bt} 2$ horizon at the summit site, which suggests the downward movement of $\mathrm{Fe}$ and $\mathrm{Al}$ with illuviation. The basic chemical properties of the studied soils are given in Table 1.

\subsection{Clay mineralogy}

$\mathrm{X}$-ray diffractograms of the soil clay fraction $(<2 \mu \mathrm{m})$ are presented in Figs. 2-5. The XRD analysis of the Oa horizon at the summit site was selected for detailed clay mineralogical description (Fig. 2). The Mg-saturated samples after glycerol solvation showed no $d$-spacing expansion beyond $1.4 \mathrm{~nm}$, which indicates the absence of smectite. After heating the K-saturated samples at $110{ }^{\circ} \mathrm{C}$, the 1.4-nm XRD peak shifted to low $d$ spacing and the intensity of the 1.0-nm peak increased, which indicates the presence of vermiculite. Because of a remaining, very small peak of approximately $1.4 \mathrm{~nm}$ also present after heating at $550{ }^{\circ} \mathrm{C}$, traces of aluminous chlorite could be identified (Fig. 2). The XRD patterns for the Mg- and K-saturated clays showed an intense 1.0-nm peak, indicating the presence of illite. Kaolinite was identified from its $0.72-$ and $0.36-\mathrm{nm}$ reflections. Both XRD peaks weakened when K-saturated clays were heated to $550{ }^{\circ} \mathrm{C}$. A tiny $\mathrm{XRD}$ peak at $0.426 \mathrm{~nm}$ was quartz.
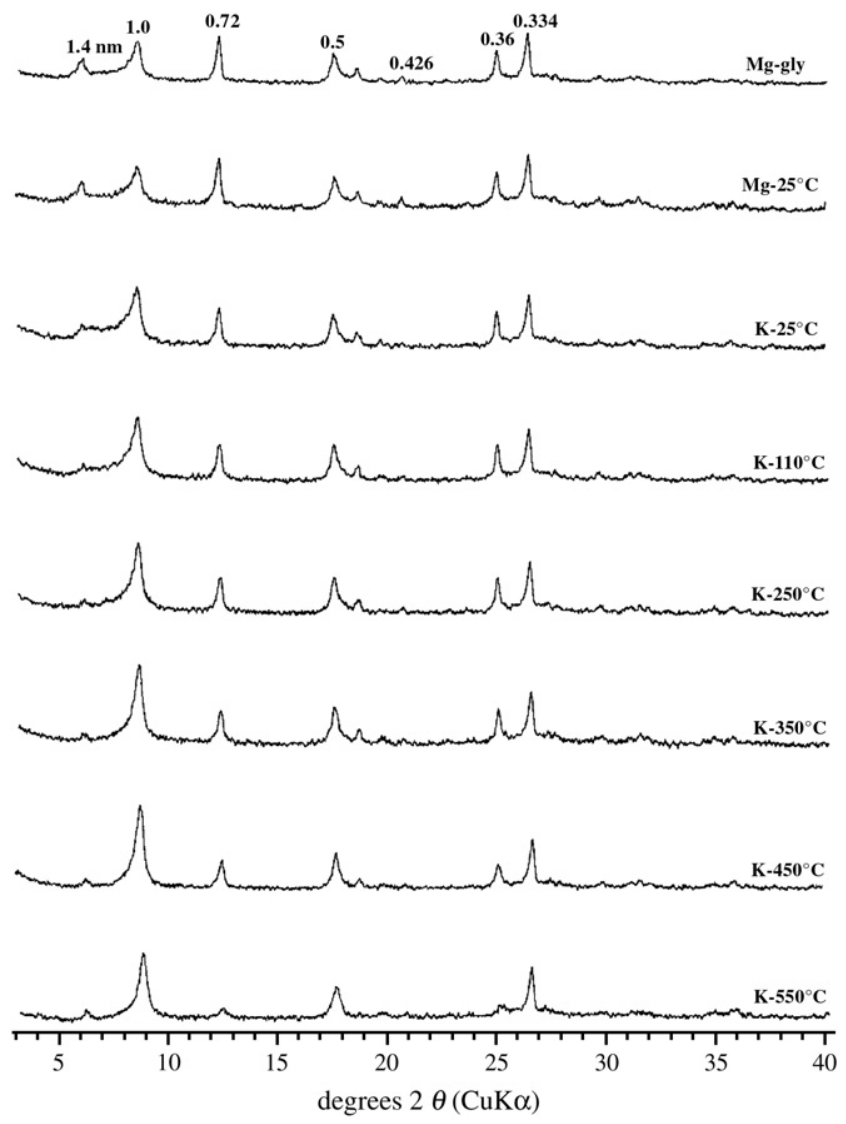

Fig. 2. The X-ray diffractograms of the clay fraction separated from the Oa horizon of soil at summit site.

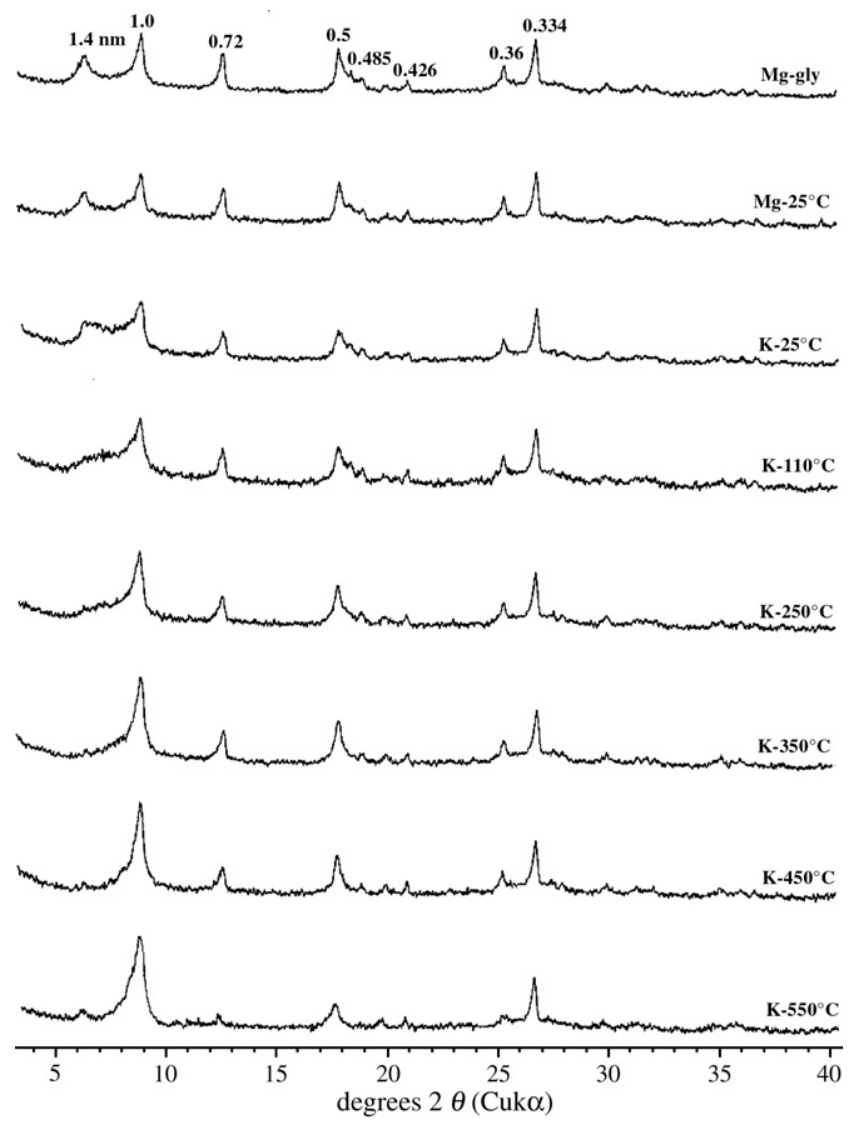

Fig. 3. The X-ray diffractograms of the clay fraction separated from the Bt1 horizon of soil at summit site.

The XRD pattern of the clay fraction from the Bt1 horizon at the summit site indicates that the clay mineralogy of the subsoil horizons is slightly different from that at the surface horizons. Hydroxy-interlayered vermiculite (HIV) was present in the Bt1 horizon (Fig. 3). The XRD pattern of the K-saturated clay at $25{ }^{\circ} \mathrm{C}$ showed a peak at $1.4 \mathrm{~nm}$, but only a broad shoulder remained at $110{ }^{\circ} \mathrm{C}$. When clays were heated to $350{ }^{\circ} \mathrm{C}$, the $1.4 \mathrm{~nm}$ peak collapsed and shifted toward $1.0 \mathrm{~nm}$. This response to clay heating indicates the loss of hydroxy-interlayer materials (Barnhisel and Bertsch, 1989; Chiang et al., 1999). The presence of gibbsite was confirmed by a tiny $0.485-\mathrm{nm}$ peak, which subsequently disappeared with thermal treatment at $350{ }^{\circ} \mathrm{C}$ (Fig. 3). Through continued leaching of bases and combined silica, 2:1 phyllosilicates can be weathered to form kaolinite or gibbsite, and kaolinite can be weathered to form a gibbsite residue (Garrels and Christ, 1965).

Because the XRD patterns of the clay fractions were similar throughout the soil profile at the footslope site, we present a representative diffractogram for the A horizon (Fig. 4). The mineralogy of the clay fractions predominantly consisted of vermiculite and illite. The $1.20-\mathrm{nm}$ diffraction peak of $\mathrm{Mg}$ saturated and glycerol-solvated samples suggested that illite might be interstratified in part with vermiculite, as shown by the broad peak intensity in the 1.0 - to $1.4-\mathrm{nm}$ region. Two weak $\mathrm{XRD}$ reflection peaks at 0.72 and $0.36 \mathrm{~nm}$ indicate the presence of kaolinite. 


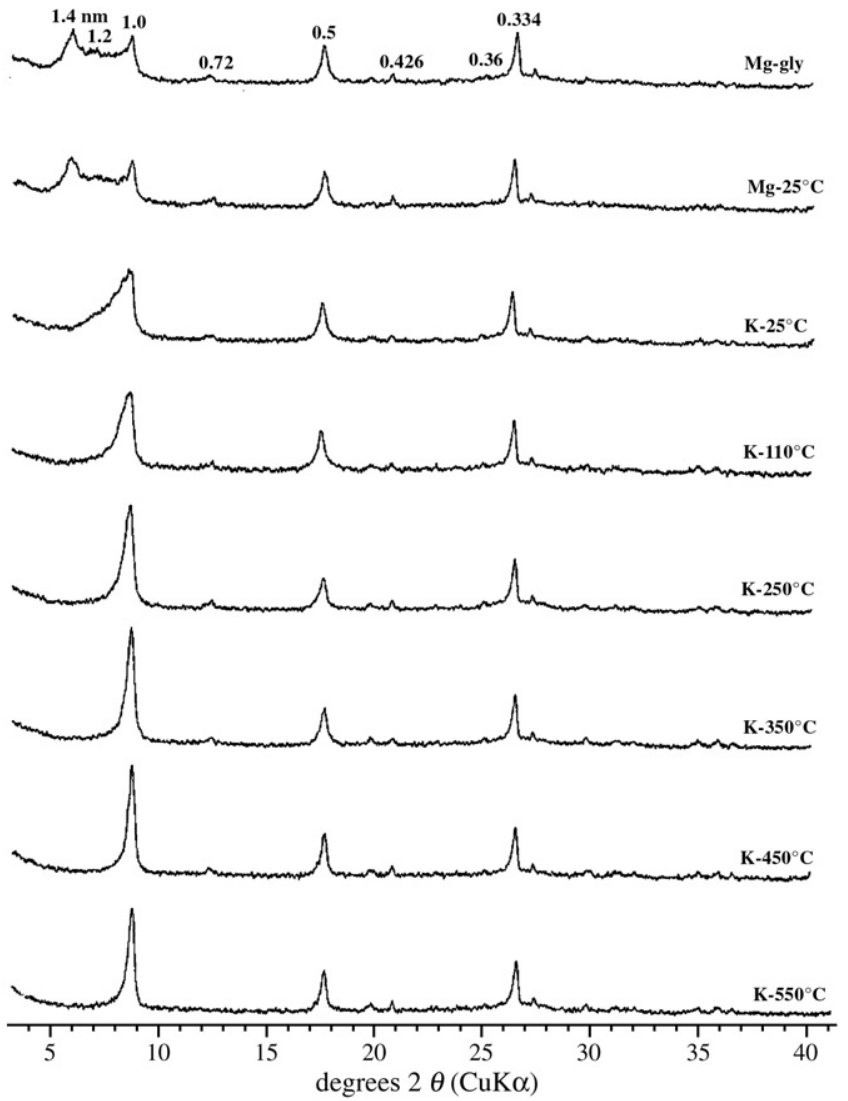

Fig. 4. The X-ray diffractograms of the clay fraction separated from the A horizon of soil at footslope site.

The distribution of clay minerals in the soil profile at the lakeshore site was uniform with depth. A representative XRD of the Oe horizon is in Fig. 5. Vermiculite, illite, and illitevermiculite mixed-layer clays were present.

Semi-quantitative compositions of clay minerals are summarized in Table 2. The surface horizon at the summit site was dominated by kaolinite and illite, with small amounts of vermiculite and trace chlorite. The soil at the summit site with pronounced profile development showed greater mineralogical difference with depth than that at other sites. Hydroxyinterlayered vermiculite (HIV) was present only in the B horizon of the summit site, which could be attributed to conditions favorable to Al-hydroxy interlayer formation such as active weathering to form $\mathrm{Al}$ ions, moderately acidic conditions, low organic matter content, and frequent wetting and drying, which are common in most Ultisols (Rich, 1968). In addition, the hydroxy-interlayered minerals might never have formed in the surface horizons of the Spodosols where organic acids would hamper $\mathrm{Al}$ deposition (April et al., 1986), because interlayer Al hydrous oxides may be removed by complex formation and chelation with organic matter. The downward leaching of $\mathrm{Fe}$ and $\mathrm{Al}$ from the surface horizons is logically enhanced for extensive interlayering behavior in the B horizon, where organic matter content decreases (Pai et al., 2004). Al-hydroxy interlayering may occur at the stage of vermiculite or after further weathering to smectite, giving rise to soil chlorite (Barnhisel and Bertsch, 1989; McBride, 1994). A large amount of kaolinite exists in the surface horizons, particularly at the summit site, because the weathering intensity has been enhanced due to greater leaching, whereas the content of kaolinite decreases in lower horizons. Long periods of weathering and leaching can result in the formation of minerals such as kaolinite in Ultisols (Sanchez and Buol, 1974).

The content and type of clay minerals were similar throughout the footslope site (Table 2), whereas kaolinite and quartz content at the surface was slightly higher than that in the mineral horizons. Vermiculite and illite were the major clay minerals in all horizons. Clay mineralogy shows few detectable changes in content of most Inceptisols as a result of pedogenesis (Allen and Fanning, 1983). The soil at the lakeshore site was predominantly vermiculite, illite, and illite-vermiculite mixed-layer clays. Almost permanent saturated conditions of soils at the lakeshore site and the absence of enough leaching for removal of some cations (e.g., $\mathrm{Mg}^{2+}, \mathrm{Ca}^{2+}$ ) inhibited the weathering processes and transformation of these minerals into smectite. Little information is available on mineral alteration in Histosol at the lakeshore site, but pedogenesis is undoubtedly minimal unless the soils are drained (Allen and Fanning, 1983).

Weathering rates of individual soils differ because of soil properties and surrounding environmental conditions (Egli et al., 2004). Therefore, the soil environment greatly influences mineral stability. The soils of a toposequence differ not only in morphological features but also as a result of erosion, transportation, and
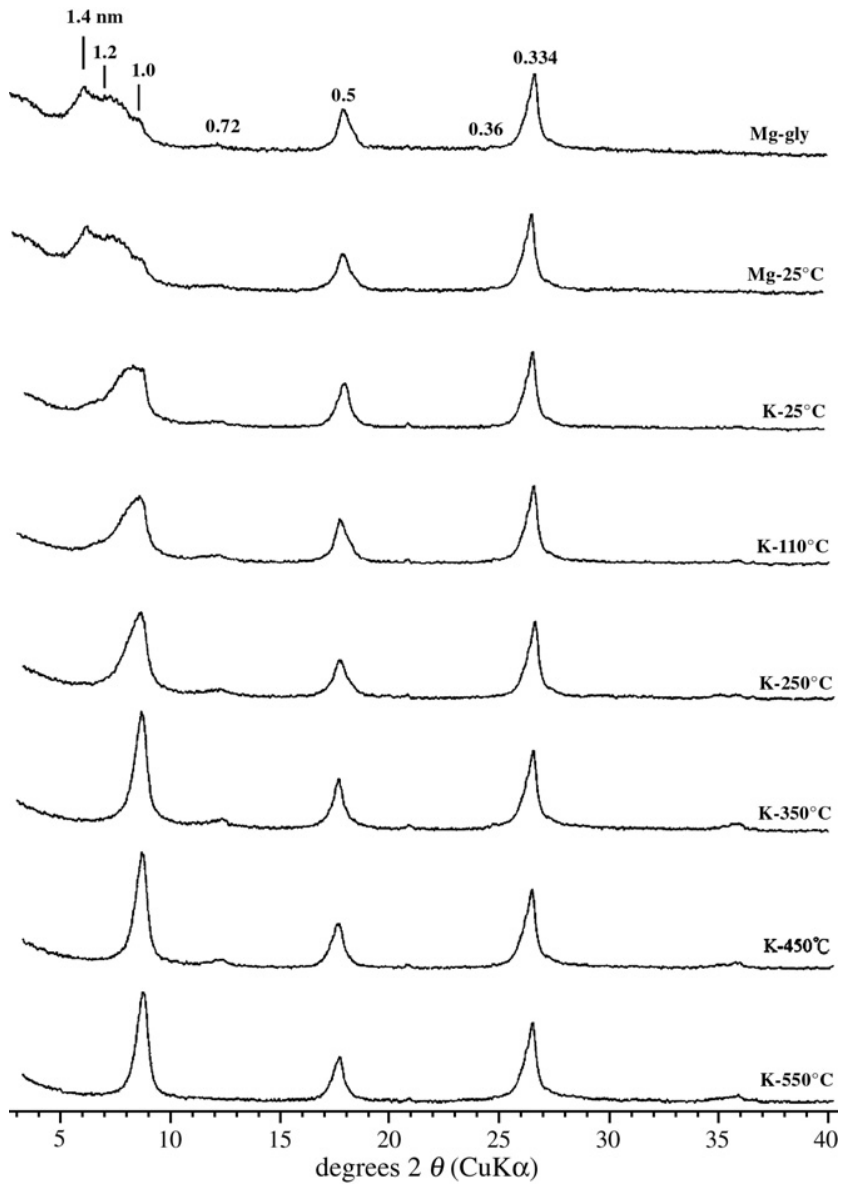

Fig. 5. The X-ray diffractograms of the clay fraction separated from the Oe horizon of soil at lakeshore site. 
Table 2

Semi-quantitative analysis of clay minerals at studied sites

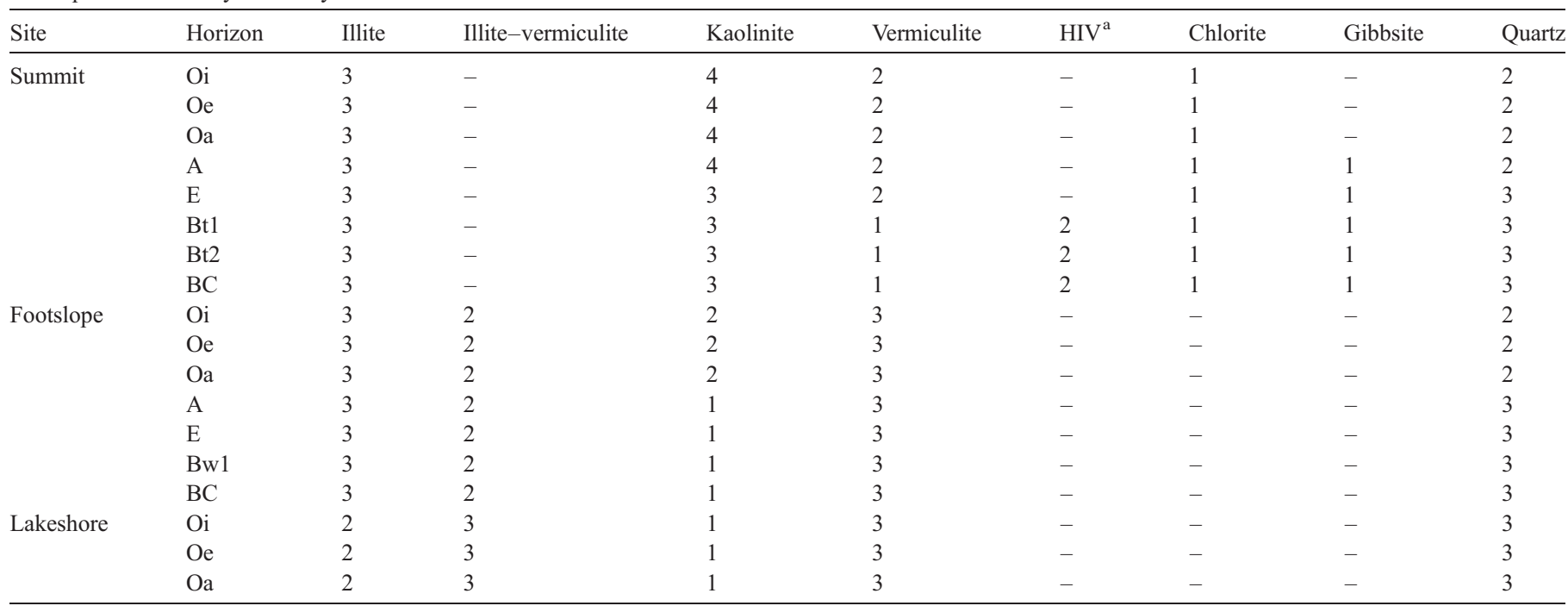

-: not detectable, 1: trace, 2: minor, 3: moderate, 4: abundant.

a HIV indicates hydroxy-interlayered vermiculite.

deposition of surface material and leaching, translocation and deposition of chemical and particulate constituents down to the deeper soil horizons (Hall, 1983). Mineralogical study of the soil horizons showed little difference in the type of clay minerals among the different locations of the toposequence, but the relative amount of clay minerals differed in weathering conditions probably because of internal drainage. Naidu et al. (1994) found that the relative abundance and distribution of clay minerals are closely related to internal drainage. However, the variation in type of clay minerals along this toposequence also has been attributed to erosion-deposition in combination with surface runoff of these forest soils.

\subsection{Layer charge of vermiculite}

The basal $d(001)$-values of the dodecylammonium-clay complexes are given in Table 3. The mean layer charge of vermiculite ranged between 0.63 and $0.78 \mathrm{cmol}_{\mathrm{c}} /\left[\mathrm{O}_{10}(\mathrm{OH})_{2}\right]$ across the 3 pedons. Except for the $\mathrm{O}$ horizons from the summit and footslope profile, the layer charge of vermiculite was greater or equal to 0.70 . Among all study sites, the mean layer charge of vermiculite increased with increasing soil depth. The higher layer charge values in the lower horizons reflect less weathering intensity as compared with those in the upper horizons (Ghabru et al., 1989). The presence of organic acids produced by plant and microbial activity and litter decay creates an intense weathering environment in the upper part of the soil profile, which decreases in strength downwards (April et al., 2004). Traditionally, weathering intensity is considered greatest in the surface horizon and gradually decreases with depth (Jackson et al., 1948). Intense weathering of clays in the surface horizons and reconstruction of clays in the lower horizon is important in some soils (Simonson, 1949).

Plant roots produce low-molecular-weight organic acids, which may accelerate mineral weathering in the rhizosphere
(Ugolini et al., 1991). With weathering, the layer charge of vermiculite appears to be lowered in the strongly acidic environment of surface horizons at all sites. In soils, $\mathrm{Al}$ and $\mathrm{Fe}$ released by weathering may be complexed with fulvic acids in solution and removed from the weathering surface, thus maintaining an uncoated mineral surface that is subjected to further weathering (Baker, 1973; Schnitzer and Kodama, 1976). Leaves lying on the forest floor are also a major source of dissolved organic substances in soil and surface water (Righi et al., 1999; Hongve et al., 2000). Continual removal of weathering products from mineral surfaces by the complex action of organic solutions presumably contributes to the relatively rapid weathering

Table 3

The $d(001)$-values of the dodecylammonium-vermiculite complexes and the mean-layer charge of vermiculite at studied sites

\begin{tabular}{llll}
\hline Site & Horizon & Mean layer charge $\left(\mathrm{cmol}_{\mathrm{c}} /\left[\mathrm{O}_{10}(\mathrm{OH})_{2}\right]\right)$ & $d(001)(\mathrm{nm})$ \\
\hline Summit & Oi & 0.63 & 2.12 \\
& Oe & 0.63 & 2.12 \\
& Oa & 0.64 & 2.13 \\
& A & 0.69 & 2.21 \\
& E & 0.70 & 2.22 \\
& Bt1 & 0.71 & 2.25 \\
& Bt2 & 0.72 & 2.27 \\
& BC & 0.72 & 2.27 \\
Footslope & Oi & 0.64 & 2.13 \\
& Oe & 0.64 & 2.13 \\
& Oa & 0.66 & 2.18 \\
& A & 0.70 & 2.22 \\
& E & 0.71 & 2.25 \\
& Bw1 & 0.75 & 2.32 \\
& BC & 0.78 & 2.37 \\
Lakeshore & Oi & 0.70 & 2.22 \\
& Oe & 0.71 & 2.25 \\
& Oa & 0.72 & 2.27 \\
\hline
\end{tabular}

$d_{001}=1.7023 \mathrm{MLC}+1.0435$

$\mathrm{MLC}=$ mean layer charge and $d$-spacings given in $\mathrm{nm}$. 
in the upper horizons (Dawson et al., 1978). Robert et al. (1979) reported that the decrease in layer charge of expandable clay minerals could be easily achieved by leaching with dilute solutions of weakly complexing organic acids. Such weathering, caused by complexing organic acids, was probably a major active process in the near-surface horizons of these soils. The upper horizon that is dominated by organic acids favors a weathering regime leading to congruent dissolution of minerals (Righi et al., 1999). In these three pedons studied, decomposition products of coniferous litter increased the forest floor acidity of the $\mathrm{O}$ and $\mathrm{A}$ horizons and promoted the rapid breakdown of illite to form vermiculite and illite-vermiculite mixedlayer clays (Pai et al., 2004).

The layer charge of the 2:1 phyllosilicates in the soils could be related to the soil profile development (Laird et al., 1988). Because of very poor drainage, relatively restricted weathering intensity and leaching occurred in soils at the lakeshore site. Therefore, in all the surface horizons, the layer charge of vermiculite of soil was highest at the lakeshore. Clay mineral composition is known to be influenced by physical properties of the soils concerned. Drainage conditions caused by topography are a critical factor in the transformation and redistribution of clay minerals. The high precipitation, high organic matter content and low $\mathrm{pH}$ in these soils suggest a potential role of organic acids in mineral weathering in subalpine forest soils.

\section{References}

Allen, B.L., Fanning, D.S., 1983. Composition and soil genesis. In: Wilding, L.P., Smeck, N.E., Hall, G.F. (Eds.), Pedogenesis and Soil Taxonomy. I. Concepts and Interactions. Elsevier, Amsterdam, pp. 141-192.

April, R.H., Hluchy, M.M., Newton, R.M., 1986. The nature of vermiculite in Adirondack soils and till. Clays Clay Miner. 34, 549-556.

April, R.H., Keller, D., Driscoll, C.T., 2004. Smectite in spodosols from the Adirondack Mountains of New York. Clay Miner. 39, 99-113.

Bailey, S.W., 1980. Summary of recommendation of AIPEA nomenclature committee. Clays Clay Miner. 28, 73-78.

Baker, W.E., 1973. The role of humic acids from Tasmanian podzolic soils in mineral degradation and metal mobilization. Geochim. Cosmochim. Acta 37, 269-281.

Barnhisel, R.I., Bertsch, P.M., 1989. Chlorite and hydroxy-interlayered vermiculite and smectite. In: Dixon, J.B., Weed, S.B. (Eds.), Minerals in Soil Environments, 2nd ed. SSSA Book Ser., vol. 1. SSSA, Madison, WI, pp. $729-788$.

Berner, R.A., Lasaga, A.C., 1989. Modeling the geochemical carbon cycle. Sci. Am. 260, 74-81.

Brindley, G.W., 1980. Quantitative X-ray mineral analysis of clays. In: Brindley, G.W., Brown, G. (Eds.), Crystal Structures of Clay Minerals and Their X-ray Identification. Mineralogical Society Monograph, vol. 5. Mineralogical Society, London, pp. 411-438.

Chen, J.S., Chiu, C.Y., 2000. Effect of topography on the composition of soil organic substances in a humid sub-tropical montane forest ecosystem. Geoderma 96, 19-30.

Chiang, H.C., Wang, M.K., Houng, K.H., White, N., Dixon, J.B., 1999. Mineralogy of B horizons in alpine forest soils of Taiwan. Soil Sci. 164, $11-122$.

Chiu, C.Y., Lai, S.Y., Lin, Y.M., Chiang, H.C., 1999. Distribution of radionuclide ${ }^{137} \mathrm{Cs}$ in the soils of a wet mountainous forest in Taiwan. Appl. Radiat. Isotopes 50, 1097-1103.

Dalsgaard, K., Basstrup, E., Bunting, B.T., 1981. The influence of topography on the development of Alfisols on calcareous clay till in Denmark. Catena 8, $111-116$.
Davidson, D.A., 1977. The subdivision of a slope profile on the basis of soil properties: a case study from Mid-Wales. Earth Surf. Processes 2, 55-61.

Dawson, H.J., Ugolini, F.C., Hrutfiord, B.F., Zachara, J., 1978. Role of soluble organics in the soil processes of a podzol, central Cascades, Washington. Soil Sci. 126, 290-296

Egli, M., Mirabella, A., Mancabelli, Satori, G., 2004. Weathering of soils in alpine areas as influenced by climate and parent material. Clays Clay Miner. 52, 287-303.

Furley, P.A., 1968. Soil formation and slope development: 2. The relationship between soil formation and gradient angle in the Oxford area. Z. Geomorphol. $12,25-42$.

Garrels, R.M., Christ, C.L., 1965. Solution, Minerals, and Equilibria. Harper and Row, New York, NY

Gee, G.W., Bauder, J.W., 1986. Particle size analysis, In: Klute, A. (Ed.), Methods of Soil Analysis. Part 1, 2nd ed. Agron. Monogr., vol. 9. ASA and SSSA, Madison, WI, pp. 383-411.

Ghabru, S.K., Mermut, A.R., Arnaud, R.J.St., 1989. Layer-charge and cationexchange characteristics of vermiculite (weathered biotite) isolated from a Gray Luvisol in Northeastern Saskatchewan. Clays Clay Miner. 37, 164-172.

Gillot, F., Righi, D., Räisänen, M.L., 2001. Layer-charge evaluation of expandable clays from a chronosequence of podzols in Finland using an alkylammonium method. Clay Miner. 36, 571-584.

Hall, G., 1983. Pedology and geomorphology. In: Wilding, L.P., Smeck, N.E., Hall, G.F. (Eds.), Pedogenesis and Soil Taxonomy. I. Concepts and Interactions. Elsevier, Amsterdam, pp. 117-140.

Ho, C.S., 1988. An Introduction to the Geology of Taiwan: Explanatory Text of the Geologic Map of Taiwan, 2nd ed. Ministry of Economic Affairs, Taipei, Taiwan. 192 pp.

Hongve, D., Van Hees, P.A.W., Lundström, U.S., 2000. Dissolved components in precipitation water percolated through forest litter. Eur. J. Soil Sci. 51, 667-677.

Jackson, M.L., 1979. Soil Chemical Analysis - Advanced Course, 2nd edn. University of Wisconsin, College of Agric., Department of Soils, Madison, WI.

Jackson, M.L., Tyler, S.A., Willis, A.L., Bourbeau, G.A., Pennington, R.P., 1948. Weathering sequence of clay-size minerals in soils and sediments: I fundamental generalizations. J. Phys. Colloid Chem. 52, 1237-1260.

Lagaly, G., 1981. Characterization of clays by organic compounds. Clay Miner. $16,1-21$.

Lagaly, G., 1982. Layer charge heterogeneity in vermiculite. Clays Clay Miner. $30,215-222$.

Lagaly, G., 1993. Layer charge determination by alkylammonium ions. In: Mermut, A.R. (Ed.), Layer Charge Characteristics of 2:1 Silicate Clay Minerals. CMS Workshop Lectures, vol. 6. The Clay Minerals Society, Boulder, CO.

Laird, D.A., Scott, A.D., Fenton, T.E., 1988. Layer charge of smectites in an Argialboll-Argiaqoll sequence. Soil Sci. Soc. Am. J. 52, 463-467.

Malla, P.B., Douglas, L.A., 1987. Layer charge properties of smectites and vermiculites: tetrahedral vs. octahedral. Soil Sci. Soc. Am. J. 51, $1362-1366$

Malla, P.B., Robert, M., Douglas, L.A., Tessier, D., Komarneni, S., 1993. Charge heterogeneity and nano-structure of 2:1 layer silicates by highresolution transmission electron microscopy. Clays Clay Miner. 41, 412-422.

McBride, M.B., 1994. Environmental Chemistry of Soils. Oxford University Press, New York.

McLean, E.O., 1982. Soil pH and lime requirement. In: Page, A.L., Miller, R.H., Keeney, D.R. (Eds.), Methods of Soil Analysis. Part 2, 2nd ed. Agron. Monogr., vol. 9. ASA and SSSA, Madison, WI, pp. 199-224.

Mehra, O.P., Jackson, M.L., 1960. Iron oxide removal from soils and clays by a dithionite-citrate system buffered with sodium bicarbonate. Clays Clay Miner. 7, 317-327.

Mermut, A.R., 1992. Problem associated with layer charge characterization. In: Mermut, A.R. (Ed.), Layer Charge Characteristics of 2:1 Silicate Clay Minerals. CMS Workshop Lectures, vol. 6. The Clay Minerals Society, Boulder, $\mathrm{CO}$.

Naidu, R., Mitchell, B.D., Mackenzie, R.C., 1994. Effect of drainage on characteristics of some soils of the Orkey Islands (U.K.). Aust. J. Soil Res. $32,519-534$ 
Olis, A.C., Malla, P.B., Douglas, L.A., 1990. The rapid estimation of the layer charges of 2:1 expanding clays from a single alkylammonium ion expansion. Clay Miner. 25, 39-50.

Pai, C.W., Wang, M.K., Wang, W.M., Houng, K.H., 1999. Smectite in iron-rich calcareous soil and black soils of Taiwan. Clays Clay Miner. 47, 389-398.

Pai, C.W., Wang, M.K., King, H.B., Chiu, C.Y., Hwong, J.L., 2004. Hydroxyinterlayered minerals of forest soils in A-Li Mountain, Taiwan. Geoderma 123, 245-255.

Rich, C.I., 1968. Hydroxy interlayers in expansible silicates. Clays Clay Miner. $16,15-30$.

Righi, D., Huber, K., Keller, C., 1999. Clay formation and podzol development from postglacial moraines in Switzerland. Clay Miner. 34, 319-332.

Rhoades, J.D., 1982. Cation exchange capacity. In: Page, A.L., Miller, R.H., Keeney, D.R. (Eds.), Methods of Soil Analysis. Part 2. Agron. Monograph, vol. 9. ASA and SSSA, Madison, WI, pp. 149-158.

Robert, M., Razzaghe-Karimi, M.H., Vicente, M.A., Veneau, G., 1979. Róle du facteur biochimique dans l'altération des minéraux silicates. Sci. Sol 3, $153-174$.
Rühlicke, G., Kohler, E.E., 1981. A simplified procedure for determining layer charge by the $n$-alkylammonium method. Clay Miner. 16, 305-307.

Sanchez, P.A., Buol, SW., 1974. Properties of some soils in the Upper Amazon Basin of Peru. Soil Sci. Soc. Am. Proc. 38, 117-121.

Schnitzer, M., Kodama, H., 1976. The dissolution of mica by fulvic acid Geoderma 15, 381-391.

Simonson, R.W., 1949. Genesis and classification of red-yellow podzolic soils Soil Sci. Soc. Am. Proc. 14, 316-319.

Soil Survey Staff, 1993. Soil Survey Manual. USDA Agricultural Handbook, vol. 18. US Government Printing Office, Washington, DC.

Soil Survey Staff, 1998. Key to Soil Taxonomy. USDA-NRCS, The 7th ed. US Government Printing Office, Washington, DC.

Ugolini, F.C., Dahlgren, R., La Manna, J., Nuhn, W., Zachars, J., 1991. Mineralogy and weathering processes in recent and holocene tephra deposits in the Pacific Northwest, USA. Geoderma 51, 277-299. 